ISSN 2236-0859

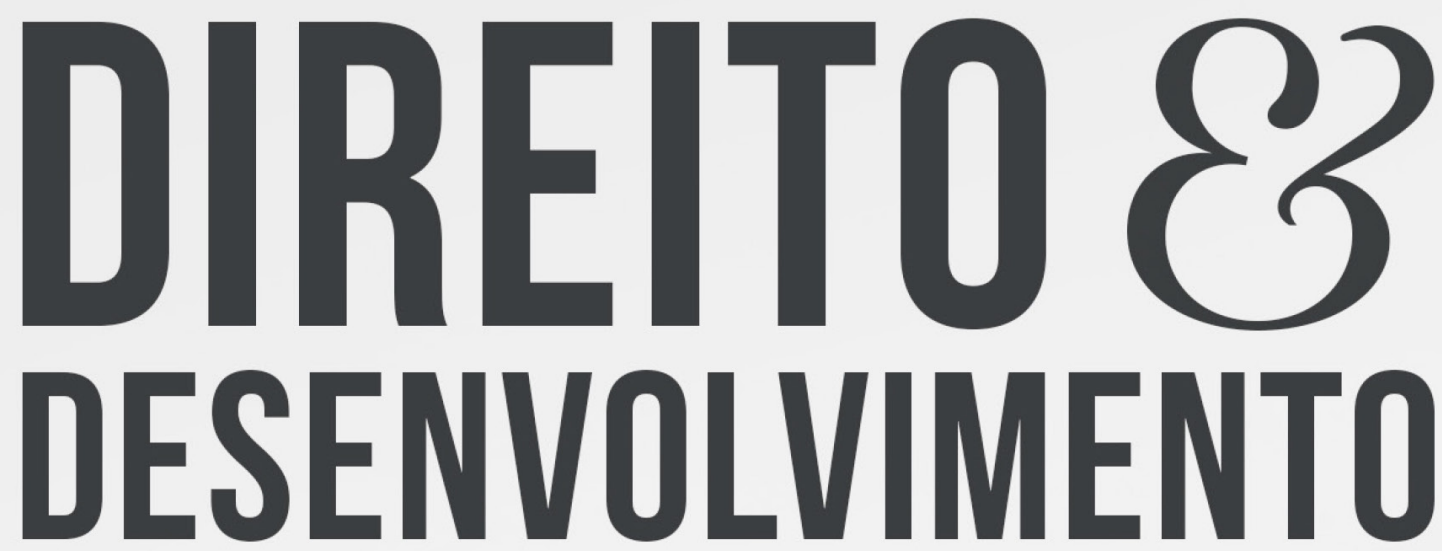

REVISTA DO PROGRAMA DE PÓS-GRADUAÇ̃̃O EM DIREITO MESTRADO EM DIREITO E DESENVOLVIMENTO SUSTENTÁVEL

BENCHMARKING E GOVERNANCA GLOBAL COMO PARÂMETROS PARA A ANÁLISE DE PROGRAMAS DE INTEGRIDADE

JULIANO HEINEN 


\title{
BENCHMARKING E GOVERNANÇA GLOBAL COMO PARÂMETROS PARA A ANÁLISE DE PROGRAMAS DE INTEGRIDADE
}

\author{
BENCHMARKING AND GLOBAL GOVERNANCE AS STANDARDS \\ FOR THE ASSESSMENT OF COMPLIANCE PROGRAMS
}

Recebido: 15/09/2019

Aprovado: 05/07/2020

Juliano Heinen ${ }^{1}$

RESUMO:

Com base no desenvolvimento teórico da governança global e da produção e aplicação de normas jurídicas por empresas e governos, o presente estudo examina as condições para que a Administração Pública brasileira realize benchmarking, ao avaliar programas de integridade desenvolvidos no âmbito de empresas em busca dos benefícios previstos pela Lei no 12.846/2013 e das demais regulamentadoras. Essa análise se justifica pela necessidade de estabelecimento um quadro de referências que dê conta dos princípios característicos da Administração Pública positivados no art. 37, caput, da CRFB/88. Incialmente, o fenômeno da governança global é apresentado como um dos modernos desdobramentos do direito internacional. Na sequência, são apresentadas as principais características dos programas de integridade no Brasil, com certos elementos de direito comparado. Posteriormente, apresenta-se o modelo de rede de integridade para explicar o funcionamento de empresas no combate à corrupção. Finalmente, lançam-se as bases para interpretar os princípios da legalidade, da moralidade, da impessoalidade, da publicidade e da eficiência de modo a tornar possível e conveniente que a Administração Pública, ao avaliar programas de integridade, leve em consideração as experiências positivas e negativas que tenham sido adquiridas por agentes do próprio mercado.

Palavras-chave: Corrupção. Benchmarking. Programas de Integridade. Governança Global. Princípios administrativos.

\begin{abstract}
:
In light of theoretical developments of global governance and of the creation and application of legal norms by companies and governments, this paper examines the conditions upon which Brazilian authorities may benchmark, when assessing compliance programs implemented by companies seeking the benefits of Federal Law No. 12,846, of 2013, and its corresponding regulation. This analysis is justified by the need of setting forth a reference framework which accounts for the principles enshrined in Article 37, caput, of the Constitution, which typically constrain public authorities. Initially, one presents global governance as a modern unfolding of

\footnotetext{
1 Doutor em Direito pela Universidade Federal do Rio Grande do Sul (UFRGS). Professor titular na Fundação Escola Superior do Ministério Público (FMP), ministrando as disciplinas de Direito Administrativo e Prática em Direito Público. Professor de pósgraduação em diversas universidades e instituições, destacando-se a Escola Superior da Magistratura Federal (ESMAFE), Escola Superior da Magistratura Estadual (AJURIS), UNIRITTER (Laurent University). Professor convidado da Escola Superior de Direito Municipal (ESDM), Fundação Escola Superior da Defensoria do RS (FESDEP), da Escola Superior da Advocacia Pública do RS (ESAPERGS) e da Escola da Magistratura do Estado do Rio de Janeiro (EMERJ). Palestrante em eventos nacionais e internacionais. Premiado nacionalmente pelo seu trabalho. Autor de dezenas de livros na área do Direito Administrativo e Constitucional. ExDefensor Público do Estado do RS. Atualmente, desempenha as funções Procurador do Estado do Rio Grande do Sul. Email: julianoheinen@hotmail.com
} 
international law. Secondly, one delves into the main features of compliance programs in Brazil and into some elements of comparative law. Thirdly, one proposes the model of compliance network to explain how companies fight corruption. Finally, one provides the basis for the construct of the principles of legality, morality, impersonality, publicity and efficiency as a means to allow authorities, when assessing compliance programs, to consider the positive and the negative experiences acquired by agents of the marketplace itself.

Keywords: Corruption. Benchmarking. Compliance Programs. Global Governance. Administrative principles.

But every clever crime is founded ultimately on some one quite simple fact-some fact that is not itself mysterious. The mystification comes in covering it up, in leading men's thoughts away from it. Gilbert Keith Chesterton

\section{INTRODUÇÃO}

Sob o pano de fundo do desenvolvimento teórico acerca da governança global, com seus efeitos sobre como empresas e governos interagem mutuamente com a produção e aplicação de normas jurídicas, o presente estudo objetiva responder à seguinte pergunta: quais são as condições para que a Administração Pública brasileira realize benchmarking, ao avaliar programas de integridade desenvolvidos no âmbito de empresas, visando a se sujeitar aos termos da Lei no 12.846/2013 e das demais regulamentadoras? A inspiração dessa pergunta vem do grande interesse que as normas que pretendem combater a corrupção têm despertado na doutrina brasileira, à conta de significativas inovações conceituais que a legislação recentemente passou a contemplar. ${ }^{2}$

O sentido teórico da indagação, por outro lado, decorre da necessidade de formulação de um quadro de referências que aptamente atenda a todos os princípios característicos do balizamento da conduta da Administração Pública. Dentre as mais importantes condicionantes, figuram os princípios positivados no art. 37, caput, da CRFB/88, a saber, os princípios da legalidade, moralidade, impessoalidade, publicidade e eficiência. Se é verdade que tais princípios servem para controlar ou, ao menos, minimizar a prática de atos desonestos na gestão da coisa pública, parece claro que, ao serem aplicados especificamente na legislação para o combate à corrupção, eles ganham em densidade e em relevância.

O referencial doutrinário, no entanto, é mais amplo do que as balizas constitucionais e legais brasileiras. A doutrina já tem fornecido conceituações suficientemente desenvolvidas da governança global como um fenômeno que pretende impactar de maneira profunda, ou, ao menos, descrever com sofisticação, os mais difusos mecanismos de interação de empresas e governos. O domínio da integridade é propício a tal análise justamente por colocar o escopo da regulação em uma perspectiva ampla. Mais do que comandos comportamentais abstratos, dotados, ou não, de respaldo estatal de caráter sancionador, a integridade se faz sentir também por induções do agir em nível prático e concreto, nem sempre punitivas em sua essência. Nessa perspectiva, importam as práticas e as orientações jurídicas internas das empresas, bem como aquelas adotadas nas relações comerciais travadas com outras entidades privadas, inclusive as de caráter de representação setorial. Ganham espaço, ainda, as práticas e orientações jurídicas

2 São exemplos de temas que têm causado preocupação: o difícil equacionamento de uma sistemática de responsabilidade objetiva, com base nos tipos descritivos positivados na lei; a convivência de diferentes sistemas punitivos, como os decorrentes da legislação contra a improbidade, de regência das licitações e da legislação penal, geral; os conflitos de competências entre diferentes órgãos, como a antiga Controladoria-Geral da União, Ministério Público, Tribunal de Contas e Advocacia Pública. 
que surgem individualmente, no âmbito da relação de cada empresa com cada autoridade regulatória responsável por um feixe da respectiva atividade econômica; e, por fim, aquelas que se extraem conjuntamente da relação entre as diversas empresas e as diversas autoridades regulatórias. A tudo isso o estudo da governança global busca dar algum grau de coerência que adequadamente responda às necessidades de um regime jurídico essencialmente transnacional, complexo e persuasivo. Com efeito: transnacionais são a atuação dos principais agentes econômicos da modernidade e as necessidades e interesses dos Estados nacionais; complexos são os interesses sociais, econômicos e políticos em jogo na modernidade; e persuasivas tendem a ser as modernas modalidades regulatórias de incentivos e desincentivos indiretos à aderência à ordem normativa.

Inserida neste contexto mais amplo, a discussão pontual sobre o exercício comparativo, por parte da Administração, de diferentes programas de integridade, desvenda mais uma faceta da aproximação conceitual e prática entre as esferas pública e privada do direito, uma noção já com um largo acervo doutrinário e jurisprudencial no Brasil. Como em possivelmente todos os fenômenos jurídicos, tal aproximação reflete uma circunstância que antes tem se manifestado na própria sociedade, em função da sua pluralização: empresas e indivíduos cada vez mais têm as suas atividades condicionadas pela atuação do Estado, o qual, por sua vez, é crescentemente pressionado para atender a demandas daqueles agentes. O efeito didático da separação entre o direito público e o direito privado, em tal cenário, perde força, na medida em que se potencializa a interpenetração entre ambos; e não raro soará legítimo, e mesmo necessário, que a Administração se valha de práticas comuns no mercado privado para melhor cumprir seu papel de garantidora de uma ordem jurídica que, de fato, reflita a versão mais justa daqueles princípios.

A reflexão sobre o tema, para além de uma contribuição teórica, pode resultar em uma gama de benefícios de ordem prático-negocial - um modelo equilibrado de compliance corporativo tem sido apontado pela doutrina especializada como uma vantagem competitiva para as empresas, com reflexos benéficos de aprimoramento para a economia como um todo. Esse modelo envolve uma análise de custo e risco voltada para a eficiência tanto do ponto de vista de aderência aos preceitos regulatórios, com ganhos sob a ótica comercial das empresas em relação a seu posicionamento no mercado; bem como sob a ótica da própria Administração. Ao reboque disso vem uma preocupação política. Não se pode perder de vista que, no Brasil, tem-se observado o uso da máquina pública para fazer dinheiro como forma de sustentação política e não apenas para enriquecimento pessoal. Ao se consolidar como uma metodologia de sustentação de um projeto de poder, a corrupção deve ganhar mesmo esse foro especial no debate jurídico. A defesa de uma governança global, assim, embora ambiciosa como proposta acadêmico-política, e quase utópica na ótica de um programa de compliance integralmente imune a falhas, tem já algumas primeiras bases teóricas sólidas.

Com a resposta à questão norteadora desse estudo, pretende-se fornecer parâmetros para que o exame dos programas de integridade, por parte da Administração, capte os mais relevantes movimentos verificados entre as próprias empresas, agregando experiências positivas e negativas que já tenham sido adquiridas na identificação das melhores práticas na construção de um modelo de combate à corrupção. Para tanto, a definição mesma de benchmarking, como busca por melhores práticas em agentes que atuam em determinado mercado, será bastante útil (PARKER, 2003, pp. 221-244). Essa técnica tem sido consagrada no mundo corporativo como um método de sistematização de processos de gestão e de solução de problemas em geral, com espelho nas melhores práticas adotadas por líderes no setor. Trata-se de uma saudável busca por excelência e pelo aproveitamento do conhecimento acumulado por outros agentes, por meio da qual é possível aprender com experiências alheias. 
Aplicada aos programas de integridade, a técnica de benchmarking pode proveitosamente socorrer empresas que estão adotando iniciativas de compliance e que, em seu próprio campo de atuação, aprimoram seus resultados mediante conhecimento adquirido por outros agentes ao enfrentarem problemas de ordem semelhante. Por meio dessa técnica, por exemplo, pode ser obtida informação sobre a estrutura do setor de integridade, os métodos de diligência apropriada, as políticas de contratação de terceiros; "os procedimentos específicos", como estatuído pelo art. 42, inciso VIII, do Decreto Federal no 8.420/2015. ${ }^{3}$

É dizer: todas as questões que devem ser devidamente enfrentadas por uma empresa que deseja não apenas constituir um programa de integridade que obedeça aos postulados legais, mas que efetivamente se destaque entre agentes do setor como tendo constituído um programa de excelência. Incentivar tal estado de coisas é bastante salutar para a Administração Pública, sobre a qual uma nova carga de atribuições e responsabilidades foi colocada pela legislação regulamentadora da Lei no 12.846/2013, a qual recebeu muitas denominações ("apelidos"): "Legislação de compliance", de "Lei de Improbidade da Pessoa Jurídica”, de "Lei Anticorrupção Empresarial”, de "Lei da Empresa Limpa" etc. A bem da didática, chama-se aqui a Lei no ${ }^{12.846 / 2013}$ pela expressão mais corriqueira e disseminada no cenário nacional. Enfim, toda a vez em que se fizer referência à norma ora comentada, será utilizada a expressão "Lei Anticorrupção" (HEINEN, 2015, p. 16).

Tal legislação vem a compor o problema da corrupção como um fenômeno transnacional e relacionado a outras formas de delinquência (FAORO, 200o, p. 8 e ss) e (BATISTA, 1991, p. 12). Logo, o debate sobre o tema deve ser enfrentado a partir de medidas que vão desde o fortalecimento das instituições e o intercâmbio de informações entre os países, até o aperfeiçoamento de mecanismos legais para a qualificação do referido combate - como é o caso da Lei ํo 12.846/2013.

\section{O MARCO DA GOVERNANCCA GLOBAL}

Do ponto de vista estritamente normativo, é apenas natural que as inquietações dos estudiosos do direito sejam tão mais alargadas quanto mais fronteiras nacionais se esteja disposto a ultrapassar ao estabelecer as características de um fenômeno jurídico. Especialmente em questões regulatórias, tal exercício nem sempre traz respostas que satisfaçam às necessidades práticas e acadêmicas, dada a dificuldade de se fixarem quais são as melhores opções, dentre as variáveis existentes. Sem embargo, para o exame aqui proposto, a validade desse exercício transfronteiriço parece se configurar quando o observador vem a se deparar com uma tendência já bastante teorizada pela doutrina: a predisposição de se buscar compreender e promover, ou, ao menos, descrever, os contornos de uma ordem jurídica pautada pela governança global. Quase alegórica, a expressão será utilizada para se referir a um objeto específico, a saber, práticas e orientações jurídicas; e a sujeitos determinados, a saber, empresas multinacionais e autoridades regulatórias estatais. Em matéria de compliance, tão extensa tem sido a produção acadêmica sobre tal objeto e tais sujeitos que, da sua essência, um núcleo central de preceitos pode ser extraído para se proceder a uma análise mais focada na realidade brasileira.

Uma justificativa para se percorrer esse caminho é a de que, diante da notória dispersão das empresas multinacionais pelo globo, ${ }^{4}$ uma visão regulatória verticalmente baseada na

3 Brasil. Decreto no 8.420/13, art. 42: "Para fins do disposto no $\S 4^{\circ}$ do art. $5^{\circ}$, o programa de integridade será avaliado, quanto a sua existência e aplicação, de acordo com os seguintes parâmetros: (...) para prevenir fraudes e ilícitos no âmbito de processos licitatórios, na execução de contratos administrativos ou em qualquer interação com o setor público, ainda que intermediada por terceiros, tal como pagamento de tributos, sujeição a fiscalizações, ou obtenção de autorizações, licenças, permissões e certidões".

4 Em referência histórico-política relevante, no campo da corrupção, a doutrina explica que "Não obstante as inúmeras e pertinentes críticas apresentadas ao processo de globalização, a liberalização econômica dela decorrente, especialmente no plano do comércio 
relação exclusiva entre governo nacional e empresa local resulta em clara deficiência. Prova disso são os problemas em matéria de preços de transferência, ${ }^{5}$ operações off-shore, standards de produtos em diferentes mercados consumidores etc. Daí que, mesmo no cenário doméstico, uma visão horizontal da regulação, abrangendo outras empresas locais, de dentro e de fora do mercado da empresa regulada, bem como outras autoridades reguladoras, é de extrema utilidade na construção de um modelo teórico sólido de maior aceitação pelos governos e pelo empresariado.

Como apontado anteriormente, o plano de análise, aqui, liga a perspectiva da governança global aos os programas de compliance também por conta dos avanços de autorregulação setorial e suprassetorial. Basta ver, para identificar o fenômeno, o impacto que a Foreign Corrupt Practices Act (FCPA), dos Estados Unidos, em vigor desde 1997, e a legislação britânica de 2011, a Bribery Act, promoveram nos setores econômicos desses países. No Brasil, isto não tem sido diferente: o setor em que empresa atua é relevante para a análise do seu programa por comando normativo expresso (art. 42, §1ํㅜㅇ, inciso IV, do Decreto no 8.420/15). Na linha da consideração de que, em quase todos Estados sociais, o princípio da eficiência veio acoplado em alguma espécie de norma (BATISTA JUNIOR, 2004, p. 156), segue-se a questão se os códigos setoriais podem ser considerados como representando as melhores práticas no setor. ${ }^{6}$ Em uma primeira aproximação, pode ser pontuado que, na lógica do art. 42 do Decreto $8.420 / 2015$, deixar de fazer uma análise caso a caso feriria os critérios que podem variar de empresa a empresa e que resultam na criação de um programa de integridade adaptado a suas peculiaridades. Mas a força persuasiva desses códigos setoriais ou suprassetoriais parece ser indubitável e talvez se possa cogitar de um ônus argumentativo para empresas daquele setor que não venham a adotar os mesmos critérios; e um bônus para aquelas que vierem a demonstrar um comprometimento ainda maior com o programa.

Em verdade, pode-se mesmo prescindir da indagação se a perspectiva da governança global pode ser escolhida no Brasil: a internacionalização da economia e do comércio jurídico, da qual o Brasil vem fazendo parte com maior intensidade nos últimos anos, já fez essa escolha pelo regulador brasileiro. Isso se manifesta tanto pela presença de multinacionais no país, geralmente associadas a estruturas societárias complexas, com pontos de contato em diversas outras jurisdições; quanto na atuação de grupos brasileiros no exterior, especialmente na América Latina. Um certo impasse subsiste aqui. Se o "problema da internacionalização" está mais do que posto, o seu equacionamento regulatório, contudo, não parece estar em condições de alcançar uma solução definitiva: esse equacionamento é uma tarefa de constantes e incrementais melhorias e adaptações. Quando já não seja operacional e econômico, é propriamente intelectual o desafio de administrar juridicamente entidades desse porte internacionalizado. Basta pensar na hipótese de uma empresa se ver na contingência de

internacional, gerou forte pressão para que os países dessem maior transparência a suas economias. Este quadro criou incentivos para a implantação de reformas em suas estruturas econômicas e administrativas de que modo a torná-los aptos as participarem dos processos de integração que se desenvolviam no plano internacional. Ou seja, fortemente influenciados pelos processos de integração ocorridos especialmente na Europa, importantes economias de países emergentes como Brasil, Argentina, México e Chile, para mencionar somente alguns exemplos de países latino-americanos, tiveram de passar por reformas em suas legislações e em suas formas de organização judiciária e administrativa de modo a torná-los mais aptos a participar dos novos movimentos de circulação de capitais, tecnologias e informação. Nesse contexto, o desenvolvimento de mecanismos de combate à corrupção passou a ser um dos principais aspectos considerados para a implementação dessas reformas”. (FURTADO, 2015. p. 24).

5 A lista de stakeholders, em matéria de preços de transferência, bem demonstra a amplitude do desafio de harmonização normativa que as atividades das multinacionais suscitam. "Transfer pricing policies permeate many facets of an MNE's business. A number of key internal and external stakeholders have a vested interest in the development, implementation, and defense of an MNE's transfer pricing policies. Key internal stakeholders include tax departments, Chief Financial Officers (CFOs), operations personnel, accounting departments, and legal counsel. Key external stakeholders include government authorities, independent auditors, and tax planning and compliance advisors." (BRONSON; JOHNSON; SULLIVAN, 2011, p.18).

6 Veja-se, por exemplo, o Código de Conduta Empresarial voltado para o compliance de hospitais privados. Disponível: http:// anahp.com.br/publicacoes-anahp/livros/codigo-de-conduta-empresarial-\%7C-compliance-para-hospitais-privados. Acesso em: 16 Jun. 2016. No plano suprassetorial, veja-se a iniciativa "Empresa Limpa". Disponível em: http://www.empresalimpa.ethos.org.br/. Acesso em: 16 Jun. 2016. 
negociar com diferentes governos (da matriz e do local onde o ato ocorreu ou ocorrerá) distintas indenizações, por um único fato ou por fatos que se "alastraram" em diferentes círculos da cadeia produtiva. Leis de bloqueio, aí, limitando a prestação de informações e documentos de caráter comercial a governos estrangeiros, claramente representam um fator de instabilidade (FERNANDES DIAS, 2015, pp. 322-367). Somem-se a isso as ações judiciais privadas, de caráter coletivo e disperso em múltiplas jurisdições, já comuns nos Estados Unidos e noticiadas como crescentes na Europa: 7 de fato, o escopo do controle prévio e posterior sobre os programas de compliance das empresas, a cada vez que um escândalo de corrupção vem a público, assume um caráter multifacetado, em que o papel das autoridades, com ou sem o protagonismo que pudesse ser desejável, designa apenas mais uma das forças em jogo.

Sean J. Griffith, acadêmico americano, aliás, vale-se justamente do caso dos escândalos de corrupção para trazer uma importante consideração sobre o mecanismo de operação das autoridades públicas. Escrevendo sobre o panorama do compliance nos Estados Unidos, ele coloca em evidência como a atuação do legislador em tais casos costuma ser limitada e, de toda sorte, logo contrabalanceada, por investidas de lobbying por parte das indústrias afetadas; e que a atuação dos prosecutors, conquanto mais discreta e menos generalista, produz impactos de maior magnitude, em função da relativa independência e do relativo insulamento político desses agentes (GRIFFITH, 2016, pp. 2118-2119). Desse exemplo americano, independentemente da sua aplicabilidade no Brasil, pode-se bem extrair um preceito geral de que os sucessos em matéria de compliance podem se originar por diferentes métodos, porque heterogêneo é o seu próprio objeto.

A defesa de um sistema de governança global, assim, representa a busca de uma normatividade perdida. Isso porque, ao largo de eventuais prescrições do direito estatal tradicional, as práticas e orientações jurídicas das empresas, e mesmo a atividade regulatória propriamente dita das autoridades, são percebidas como separadas por certa incoerência e por movimentos de fuga. Os campos jurídicos em que isso pode ser feito são vários: em um sistema de direitos humanos; em um sistema de proteção ambiental; em um sistema financeiro mundial; em sistema esportivo mundial; em um sistema de arbitragem internacional; em um sistema energético mundial; em um sistema de investimentos estrangeiros etc. Em todos esses casos, meramente reconhecer que uma regulação de qualidade pode influenciar diretamente as práticas e orientações jurídicas das empresas parece ser o primeiro passo para uma tão desejada aderência regulatória. Atingir semelhante objetivo, contudo, não está ao fácil alcance dos governos e, sem dúvida, a doutrina muito tem a construir como forma de auxílio nessa tarefa.

A perspectiva da governança em matéria de compliance deve se referir, por fim, a algumas implicações extracorporativas e internacionais. Ambas sinalizam e alimentam o interesse na criação de instrumentos jurídicos de aprimoramento regulatório. A visão extracorporativa do compliance convida a um olhar para as pessoas jurídicas que, em vez de se centrar unicamente em seus agentes internos, torna juridicamente relevantes os compromissos que as empresas devem ter com os seus agentes - não exatamente externos, mas - laterais. Daí a menção aos princípios da OCDE especialmente desenvolvidos para empresas listadas no mercado de capitais, tutelando: (i) o direito dos acionistas; (ii) o tratamento equitativo dos acionistas; (iii) o papel dos stakeholders na governança corporativa; (iv) informações e transparência; (v) responsabilidades do Conselho (FREMOND; CAPAUL, 2016, p. 6). Desses agentes laterais, podem-se esperar esforços e incentivos a que a promoção do compliance seja feita da melhor maneira possível. Há, no entanto, repercussões tipicamente internacionais que alargam ainda mais o raio da análise jurídica que deve ser feita em matéria de compliance. A vocação global

7 PRICE-fixing. No truck with cartels. The Economist: Londres, 04 Jun. 2016. Disponível em: http://www.economist.com/news/ business/21699957-expensive-times-companies-accused-collusion-no-truck-cartels. Acesso em: 12 Jun. 2016. 
para o tratamento adequado dos novos desafios regulatórios envolvendo empresas e governos esbarra, de maneira provocante, na própria barreira que tradicionalmente se imputa ao direito internacional. A doutrina tem sugerido, aí também, uma reinterpretação de categorias. Nas palavras de Marti Koskenniemi, a posição mesma da disciplina do direito internacional, a um só tempo distante e próxima a todos esses problemas socioeconômicos e, afinal, jurídicos, ganha destaque:

O direito internacional aparece frequentemente como a única superfície sob a qual a governança administrativa pode ser desafiada, o único vocabulário com um horizonte de transcendência - mesmo se, ou talvez precisamente porque aquele horizonte não é facilmente traduzido em outro projeto institucional. Penso, muitas vezes, no direito internacional como uma espécie de fé secular. Quando Estados poderosos ocupam-se em guerras imperiais, a globalização desloca comunidades ou companhias transnacionais causam destruição ao meio ambiente, e onde governos nacionais se mostram corruptos ou ineficazes, ouve-se comumente um clamor ao direito internacional. Este aparece aqui menos como regra ou instituição, mas como um espaço de vocabulários de justiça e bondade, solidariedade, responsabilidade e - fé. (2009, p. 278)

Os aportes da governança global, aqui, serão recortados para o campo do compliance corporativo, o qual, de certa maneira, reflete-se em quase todos exemplos acima citados, mas que se circunscreve de maneira toda própria no combate à corrupção. Assim se passa por conta da excepcional dimensão que a aderência regulatória, de onde quer que a norma jurídica esteja vindo, assume em determinadas empresas. Não ignorado pelos Estados, o problema da aderência regulatória tem se destacado de maneira tão importante que se consolidou em diversas jurisdições, inclusive no Brasil, o postulado de que as próprias pessoas jurídicas são responsáveis por estruturar aparatos internos de prevenção, apuração e responsabilização de ilícitos cometidos por seus funcionários e por terceiros com quem tenham determinados vínculos. Falhando nessa esfera, as empresas se sujeitam a sanções complementares àquelas impostas pelo descumprimento puro e simples de um determinado comando regulatório, o que bem explica como o compliance, por si só, virou um negócio bilionário de escala mundial; e que, não à toa, perpassa iniciativas do próprio poder público brasileiro para tentar instrumentalizar melhor o controle interno. ${ }^{8}$

\section{PROGRAMAS DE INTEGRIDADE}

Os programas de integridade não são novos no setor privado, tendo em vista que implementados francamente nas corporações. Eles visam a prevenir desvios, abusos ou ilegalidade cometidos pelos agentes que atuam em nome das pessoas jurídicas, a fim de não as prejudicar. Então, a figura da compliance é uma prática que impõe às pessoas a aderência à lei e às boas práticas, inclusive aquelas dispostas em códigos de ética interna das empresas. Logo, tais programas de integridade implementam mecanismos indutores ao comply. Não se trata de uma ferramenta para fiscalização, porque sua principal função serve à prevenção. Com estes mecanismos, facilita-se o controle e procura-se evitar e detectar eventuais desvios que ocorram ou possam vir a ocorrer. Esse aparato se tornou uma ferramenta essencial no mercado corporativo, especialmente para aquelas pessoas jurídicas sujeitas a controles externos e que, em sua linha usual de negócios, desempenham atividades de risco comercial, regulatório e 8 É este, argumentavelmente, o caso da PEC 45/20o9, que acrescenta o inciso XXIII ao art. 37 da Constituição Federal, dispondo sobre as atividades do sistema de controle interno nos seguintes termos: "As atividades do sistema de controle interno da União, dos Estados, do Distrito Federal e dos Municípios a que faz referência o art. 74, essenciais ao funcionamento da administração pública, contemplarão em especial as funções de ouvidoria, controladoria, auditoria governamental e correição, e serão desempenhadas por órgãos de natureza permanente, e exercidas por servidores organizados em carreiras específicas na forma da lei”. 
comportamental. Logo, os programas de compliance ou programas de integridade possuem dois objetivos: (a) evitar ao máximo a prática de atos corruptos no âmbito da pessoa jurídica; (b) caso ainda assim se visualize uma conduta ilícita, o programa ajudará a reduzir as penas eventualmente aplicadas (HEINEN, 2015, pp. 175-177).

Não ignorando este instituto, o artigo $7^{\circ}$, inciso VIII, da Lei no 12.846/2013, percebeu que poderia ofertar uma atenuante, caso as empresas detivessem mecanismos e procedimentos internos de integridade, auditoria e incentivo à denúncia de irregularidades, bem como a aplicação efetiva de códigos de ética e de conduta no âmbito da pessoa jurídica - estabelecidos em regulamento do Poder Executivo federal (artigo $7^{\circ}$, parágrafo único). Vejase que a Lei Anticorrupção não isentou de pena as pessoas jurídicas, mas apenas diminuiu os sancionamentos. Vale notar que Nos Estados Unidos, programas deste matiz devem ser efetivos e baseados em uma estrutura mínima de premissas, que são retiradas, por exemplo, dos Principles of Federal Prosecution of Business Organizations (FCPA). Neste país não se admite programas figurativos, ou seja, meramente formais, despidos de um substrato. Claro que tais programas não devem ser onerosos e burocráticos ao ponto de prejudicar a própria atividade empresarial. $\mathrm{O}$ que merece ser dito é que não há uma estruturação pronta a sua implementação, sendo que a experiência internacional será de muita valia aqui. O instituto em questão tornou-se tão importante que as empresas que não o implementam perdem atratividade no mercado, dado que os investidores (stakeholders) contabilizam este tipo de ferramenta como uma oportunidade ou não de investimento seguro, principalmente em termos de cenário financeiro. Assim, o compliance tornou-se uma verdadeira exigência do mundo capitalista.

O programa de compliance tem por meta, então, prevenir, detectar e corrigir eventuais práticas ilícitas, contrárias também às normas internas da empresa. Além disso, fomenta uma orientação de como os colaboradores (funcionários ou terceiros) devem agir. As políticas internas, assim estabelecidas, criam uma "cultura de boas práticas", inserindo um ideário no limiar da pessoa jurídica. Em outros países, o mencionado programa pode dar à empresa a absolvição - não é o caso da legislação brasileira. E, de quebra, fomenta uma qualidade maior na imagem da empresa perante o mercado e seus acionistas. Assim, muito embora o mercado, por si mesmo, tenha impulsionado a criação deste tipo de ferramenta de controle interno, a Lei no 12.846/2013 não desmereceu este esforço. Tanto que considerou como sendo uma atenuante, quando da aplicação das sanções, o que remete à observação de a existência destes programas de controle e de auditoria não afasta a culpabilidade da empresa, mesmo que a referida ferramenta seja efetiva. Neste ponto, nota-se que a Lei no $12.846 / 2013$ se afastou da $U$. K. Bribery Act - legislação britânica que trata do tema.

Na trilha do que determinou a Lei no $12.846 / 2013$, a União, no seu âmbito, positivou relevante regra sobre o tema no art. 41, caput, do Decreto federal no 8.420/2015. Aqui ficou definido que o programa consiste em um "[...] conjunto de mecanismos e procedimentos internos de integridade, auditoria e incentivo à denúncia de irregularidades e na aplicação efetiva de códigos de ética e de conduta, políticas e diretrizes com objetivo de detectar e sanar desvios, fraudes, irregularidades e atos ilícitos praticados contra a administração pública, nacional ou estrangeira”. O parágrafo único do mesmo dispositivo, ao seu turno, traz uma regra bastante interessante: impõe a constante adaptabilidade de tal instituto, frente às peculiaridades de cada pessoa jurídica e a realidade que se processa. Por exemplo: ele deve ser "[...] atualizado de acordo com as características e riscos atuais das atividades de cada pessoa jurídica, a qual por sua vez deve garantir o constante aprimoramento e adaptação do referido programa, visando garantir sua efetividade." 
Deve ser notado que várias providências de cunho estrutural merecem estar presentes, como a independência do órgão responsável pela área de compliance, a existência de procedimentos e fluxogramas conhecidos e previamente constituídos, a existência de canais que permitam o recebimento de denúncias. Tais denúncias devem guardar a confidencialidade, bem como permitir que o delator seja imune a retaliações. Será, ainda, fundamental a existência de mapeamento dos riscos, assim com que a alta administração da empresa se comprometa com os programas de combate à corrupção. A proeminência da governança corporativa no mercado de ações (bolsa de valores), nos Níveis I e II, é um bom exemplo de exigência do mercado para a adoção de um maior número de mecanismos de compliance. Complementando este dispositivo, a Controladoria-Geral da União (CGU) editou a Portaria CGU no 909/2015, que estabelece critérios para a avaliação dos programas de integridade constituídos pelas empresas. Tal ato normativo estabelece, então, três critérios para compreender o referido instituto nas empresas: tamanho, perfil de atuação e posicionamento no mercado.

Sendo assim, a União definitivamente "tarifou" os itens a serem considerados para definir os programas de integridade no momento da dosimetria da pena, quando, então, podese atenuá-la. Passa-se a considerar se existe ou é aplicado um programa efetivo de compliance a partir da existência dos critérios listados pelo artigo 42 e da portaria mencionada. Contudo, muitos programas podem não deter todos os mecanismos mencionados, até porque se está a tratar de sociedades com perfis, portes e padrões econômicos bastante díspares. A metodologia compreendida a partir do benchmark, vale a pena adiantar desde logo, não deve ser estática e formal, mas dinâmica e substancial. Como será explorado mais abaixo, um ponto central dessa postura estará não apenas na identificação das melhores práticas, como se existisse uma competição entre as empresas, mas, igualmente, na busca pelas melhores análises de riscos, os quais estão presentes, em maior ou menor medida, em todos os setores econômicos. Em suma: a Administração Pública deve conhecer os riscos e deve dar a conhecer tais riscos; e, ao assim fazer, é óbvio que as empresas podem prestar relevante contribuição.

Há documentos internacionais que relacionam uma série de requisitos para se considerar inserido o instituto em foco em uma dada empresa, como o OCDE - Guia de Boas Práticas sobre Controles Internos, Ética e Compliance, UNODC - Um Programa de Ética AntiCorrupção e de Compliance para Empresas ${ }^{9}$ (produzido pela Organização das Nações Unidas - ONU). Outro documento bastante expressivo no tema é A Resource Guide to the FCPA U.S. Foreign Corrupt Practices Act, produzido pelo Departamento de Justiça norte-americano. ${ }^{10}$ Esse último documento é produto de um trabalho que teve por foco justamente o benchmarking, tanto que contou com a participação efetiva de indústrias sediadas nos Estados Unidos.

Em resumo, defende-se a necessidade de que se tenham códigos de ética interna, envolvimento da alta administração, desvinculação da área de compliance com a área de gestão da empresa, treinamento, auditorias e análise de riscos periódicas, meios pelos quais se possam veicular denúncias, canais de comunicação efetivos, transparências nas ações etc. Muitos desses itens foram levados em conta pelo art. 42, § 1o, do Decreto federal oㅜ 8.420/2015 na avaliação dos parâmetros de que trata este artigo, sobretudo a se considerar o porte e especificidades da pessoa jurídica. ${ }^{11}$

9 An Anti-Corruption Ethics and Compliance Programme for Business: A Practical Guide (United Nations, Setembro de 2013). Disponível em: https://www.unodc.org/documents/corruption/Publications/2013/13-84498_Ebook.pdf.

10 E, claro, existem tantas outras referências no tema, ou seja, documentos internacionais, de outras Nações ou de soft law que definem os elementos que compõe um programa de compliance: Asia-Pacific Economic Cooperation - AntiCorruption Code of Conduct for Business; International Chamber of Commerce - ICC Rules on Combating Corruption; Transparency InternationalBusiness Principles for Countering Bribery; United Nations Global Compact - The Ten Principles; World Bank - Integrity Compliance Guidelines; World Economic Forum - Partnering Against Corruption - Principles for Countering Bribery.

11 "Por outro lado, devemos destacar que a Lei no 12.846/20136 omitiu-se em prever a possibilidade de o Poder Público impor regras de compliance às pessoas jurídicas, até como medidas preventivas no combate à corrupção. Enfim, não há pevisão de que o Poder Público possa determinar que certas pessoas jurídicas acusadas devam deter certos mecanismos de controle dos atos que possam vir a se configurar como sendo atos de corrupção. Exemplificando: imagine que se estivesse a perpetrar determinada investigação, diante 
Diante desse contexto, o conceito jurídico indeterminado constante no art. $7^{\mathbf{0}}$, inciso VIII, da Lei Anticorrupção perdeu sua abstração no momento em que a Administração Pública federal passou a se autorregular. ${ }^{12}$ Assim, a discricionariedade conferida pela norma foi bastante reduzida pelo Decreto Federal no 8.420/2015. A desvantagem desta opção infralegal consiste na perda da flexibilidade, por conta de poder deixar de ver o mérito diante de casos individuais, a fim de graduar uma maior ou menor complexidade do programa de compliance. Deve-se insistir: esta opção deixa bastante prejudicado o método de trabalho que procura trazer razoabilidade à luz da experiência, muito embora seja certo que o cidadão não fica exposto e à mercê do Poder Público, especialmente quando se percebem deficiências na motivação dos atos administrativos, o que é suscita a busca por equilíbrio entre vantagens e desvantagens de cada opção (CANE, 2011, p. 141).

O certo é que um dos principais objetivos da referida legislação consiste em aumentar o nível de cumprimento voluntário das obrigações, promovendo o emprego adequado de recursos e instrumentos de controle, por meio de medidas e procedimentos que os agentes econômicos previamente se comprometam a implantar. Soa necessário, para tanto, ultrapassar a abordagem tradicional baseada apenas em modelos padronizados para toda e qualquer empresa - especialmente quando elas atuam em market share diferentes (OCDE, 2004, pp. 3745). Além de técnica válida para os negócios, tal atitude revela, em seu âmago, um fundamento filosófico-científico geral (CARVALHO, 2015, p. 38) e um norte particular em matéria regulatória (ARAGÃO, 2013, pp. 28-29).

\section{DA REDE DE INTEGRIDADE}

Por convicção moral, por incentivos econômicos ou por puro peso regulatório, o fato é que começa a se formar - o que, por falta de um melhor nome, poder-se-ia designar - uma rede de integridade entre as empresas. Essa rede abrange uma cadeia de pessoas jurídicas, em grandes conglomerados econômicos; clientes e fornecedores de grande e pequeno porte; terceiros prestadores de serviços em geral; e funcionários. Todos esses agentes, orbitando o ecossistema das empresas, passam a se submeter ao escopo de seus esforços de aderência regulatória.

Um paralelo pode ser traçado entre esse fenômeno e um desdobramento importante na ordem global, cujos efeitos sobre a área de compliance mereceriam todo um estudo em separado: os movimentos de uniformização do direito privado e, como contraponto, de popularização de aplicação do direito estrangeiro por juízes locais, em determinados casos. Ao resolver disputas mediante a aproximação de ordens normativas, opera-se mentalmente de forma similar à que leva à adoção de parâmetros de condutas semelhantes por agentes distintos de uma dada cadeia econômica. Por trás dos dois fenômenos busca-se encontrar o melhor direito e criar para os respectivos agentes, inclusive para os juízes, deveres anexos àqueles que ordinariamente seriam exigidos por sua condição jurídica. ${ }^{13}$

de mera suspeita de ocorrência de ilicitudes. Nesta situação, poder-se-ia impor às empresas que provassem a origem de patrimônio ou determinar o fornecimento irrestrito a dados ou a documentos de sua posse; ou que a sociedade custeasse diligências; ou que fosse franqueada uma auditoria etc. Contudo, a Lei Anticorrupção, como se disse, foi omissa neste sentido" (HEINEN, 2015, pp. 183-184). 12 Em linhas gerais, o poder regulamentar é aquele que é estatuído por via geral a autoridades diversas do Parlamento, concentrando, no chefe do Poder Executivo - precipuamente -, a função de tomar as medidas necessárias ao bom funcionamento da ação administrativa (CE, 7 fev. 1936, Jamart, Gr. Ar.). Conferir, ainda: (RIVERO,1983, pp. 69-70), ou consultar a edição portuguesa: (RIVERO, 1981, pp. 77-78).

13 "Com efeito, a ideia de horizontalidade, inerente à rede, faz com que os diversos ordenamentos jurídicos possam ser enxergado como integrantes de uma complexa rede transnacional, exsurgindo o papel dos juízes e demais profissionais do direito não apenas como aplicadores do direito do foro, mas sim como verdadeiros mediadores dessa complexidade cosmopolita." (VALENTE DOS REIS, 2016, p. 87) Texto gentilmente cedido pelo Autor. 
No plano puramente corporativo-contratual, isso se materializa na inclusão de cláusulas anticorrupção em contratos comerciais em geral, e no entrecruzamento de práticas e orientações jurídicas que as empresas vão exigindo umas das outras, como decorrência dos parâmetros adotados por elas próprias adotados. É comum, a esse respeito, no âmbito de vínculos comerciais, sobretudo aqueles relacionados a empresas multinacionais, que as empresas parceiras reciprocamente se submetam a programas de integridade umas das outras. Esse fenômeno não exatamente surpreende ao se pensar nos impactos, por vezes financeiramente severos, de diversas legislações anticorrupção sobre pessoas jurídicas envolvidas em atos ilícitos, ainda que indiretamente. Em termos normativos, de toda forma, é interessante especular sobre a extensão que essa verdadeira fonte obrigacional vai assumir no cenário jurídico, dada a proximidade muito maior que existe entre parceiros comerciais, em comparação com a distância que separa empresas e reguladores. Medidas concretas no dia-adia das empresas acabam surgindo dessa dinâmica, possivelmente mais impactantes na medida mesma em que não se pautam tão fortemente na desconfiança, como com frequência ocorre na relação horizontal com as autoridades. É o caso de sessões de treinamento de funcionários; do compartilhamento e observância de certa metodologia para o recrutamento de terceiros; do compartilhamento sobre informações acerca das pessoas que ocupam posições estratégias na hierarquia etc.

As cláusulas anticorrupção, relevantemente, não apenas preveem a rescisão contratual, em caso de comportamento ilícito do parceiro comercial, retirando o substrato econômico direta ou indiretamente ligado à conduta, como muitas vezes é acoplada a uma cláusula de auditoria. Essa última abre à parceira comercial a possibilidade de aprofundar, ainda mais, as investigações sobre condutas passadas, especialmente para o fim de controlar os pagamentos realizados e detectar eventuais propinas pagas diretamente a agentes governamentais ou a empresas de fachada, com fins escusos. Sendo levado a cabo, em geral, por auditorias internas e externas, o mecanismo potencializa, de maneira formidável, a abrangência das investigações suscitadas por denúncias de irregularidades. Com isso alarga-se o campo de aplicação do direito imperativo que os governos editam em matéria fiscal e contábil, dentre tantos outros exemplos. Prática já corriqueira em grandes empresas no Brasil, essa solidariedade normativa que vai se criando no setor privado, se não perde de vista os objetivos públicos contemplados em diplomas regulatórios dos mais variados escopos, em sede governamental, também tem merecido atenção de entidades produtoras de soft law: basta ver, a esse respeito, as diferentes estratégias contratuais e normativas sugeridas pela pela Câmara Internacional de Comércio para enfrentar o problema (ICC, 2012, p. 30).

Logo, verifica-se que o combate à corrupção tem se valido da sede típica da autonomia da vontade privada para irradiar efeitos entre as partes e terceiros, em momentos anteriores e posteriores ao contrato. Uma forma inteligente de atestar a efetividade de iniciativas a esse respeito, aliás, está em rastrear, em investigações, os casos em que a empresa deixou de estabelecer ou cessou uma parceria comercial por identificar riscos elevados em um procedimento de due dilligence com terceiros. Mais que chamarem a atenção das autoridades para a caracterização desse risco em outras empresas, dados dessa natureza servem para comprovar como o risco é tratado pela própria empresa investigada. Com isso se pode retratar bem a dimensão da seriedade do programa, até porque podem existir situações excepcionais em que a empresa necessita manter uma relação comercial com terceiro de alto risco: a excepcionalidade, aí, será justificada, naturalmente, com a demonstração de que medidas de remediação foram tomadas. 
Acordos de vontade dessa natureza, aliás, podem e soem incluir o próprio poder público, em seus contratos. ${ }^{14}$ Depois de introduzida em muitos contratos por força da aplicação de diretrizes do Banco Mundial em casos de financiamentos internacionais - fenômeno que, por si só, retrata uma vertente direta da governança global, permeando o direito interno - a utilização da cláusula tem sido positivada por entes relevantes no cenário nacional e já pode ser divisada como uma tendência. ${ }^{15}$

Semelhante movimento de atuação no âmbito desta rede denota uma inspiração de correção entre as empresas que poderia preocupar, se acaso fosse fugaz. A doutrina, todavia, tem demonstrado uma vocação de perenidade em tal postura, justamente porque, para além de um incentivo moral, ao promoverem iniciativas de compliance as empresas também atendem a uma demanda econômica por eficiência. Robert C. Bird e Stephen Kim Park, professores na Universidade de Connecticut, nos Estados Unidos, sustentaram em trabalho recente como o compliance corporativo pode se tornar uma vantagem competitiva para as empresas (2017, p. 1). Os achados contidos nesse estudo assentam-se na premissa de que a aderência regulatória não é um ato binário, de caráter "tudo ou nada", mas, sim, um mecanismo dinâmico e responsivo a opções constantes das empresas. Justamente por isso, apontam os acadêmicos, é possível a construção de um modelo explicativo para o comportamento das empresas e para o dimensionamento dos patamares de risco e de retorno que as mesmas devem buscar atender. Nessa equação podem entrar "penalidades formais, impactos reputacionais nos consumidores, custos em relação ao moral da organização, relacionamento com os reguladores e percepção da sociedade" (2017, p. 14).

No âmbito desta rede de compliance, as empresas têm desempenhado um papel cada vez mais ousado de proteção da ordem jurídica e da lisura na gestão da coisa pública, em espaços a um só tempo óbvios, mas previamente considerados invioláveis por entes privados. 14 Ceará. EXTRATO DE ADITIVO AO CONTRATO № o12/CIDADES/2009 (...) VIII - OBJETO: DA CLÁUSULAANTICORRUPÇ̃̃O E ANTIFRAUDE: A Cláusula 1.9 do presente Contrato passará a ter a seguinte redação: 1.9. FRAUDE E CORRUPÇÃO 1.9.1 Os licitantes devem observar e o contratado deve observar e fazer observar, por seus fornecedores e subcontratados, se admitida subcontratação, o mais alto padrão de ética durante todo o processo de licitação, de contratação e de execução do objeto contratual. 1.9.1.1 Para os propósitos desta cláusula, devem ser evitadas e inibidas as seguintes práticas: (i) "prática corrupta": oferecer, dar, receber ou solicitar, direta ou indiretamente, qualquer vantagem com o objetivo de influenciar a ação de servido público no processo de licitação ou na execução do contrato; (ii) "prática fraudulenta": a falsificação ou omissão dos fatos, com o objetivo de influenciar o processo de licitação ou de execução do contrato; (iii) "prática conluiada": esquematizar ou estabelecer um acordo entre dois ou mais licitantes, com ou sem o conhecimento de representantes ou prepostos do órgão licitador, visando estabelecer preços em níveis artificiais e não-competitivos; (iv) "prática coercitiva”: causar dano ou ameaçar causar dano, direta ou indiretamente, às pessoas ou sua propriedade, visando influenciar sua participação em um processo licitatório ou afetar a execução do contrato. 1.9.2 Considerando os propósitos das cláusulas 1.9.1 e 1.9.1.1. deste Edital, o licitante vencedor, como condição para a contratação, deverá concordar e autorizar que, na hipótese de o contrato vir a ser financiado, em parte ou integralmente, por organismo financeiro multilateral, mediante aditamento ou reembolso, permitirá que o organismo financeiro e/ou pessoas por ele formalmente indicadas possam inspecionar o local de execução do contrato. 1.9.3 Na hipótese de financiamento, parcial ou integral, por organismo financeiro multilateral, mediante aditamento ou reembolso, considera-se também como prática atentatória ao mais alto padrão de ética: 1.9.3.1 "prática obstrutiva":(a) destruir, falsificar, alterar ou ocultar provas em inspeções ou fazer declarações falsas aos representantes do organismo financeiro multilateral, com o objetivo de impedir materialmente a apuração de alegações de prática prevista na cláusula 3.1.1 deste Edital; (b) atos cuja intenção seja impedir materialmente o exercício do direito de o organismo financeiro multilateral promover inspeção. 1.9.4 O organismo financeiro multilateral poderá cancelar a parcela do empréstimo relativa ao contrato se, a qualquer momento, comprovar a prática corrupta, fraudulenta, conluiada ou coercitiva por parte dos representantes do contratante/mutuário ou do contratado, no decorrer da licitação ou da execução do contrato, sem que o contratante/ mutuário tenha adotado as medidas necessárias e apropriadas, satisfatórias ao organismo financeiro multilateral, para a correção dos desvios. 1.9.5 O contratante, garantida a prévia defesa, aplicará as sanções administrativas pertinentes, previstas na Lei no 8.666 de 21 de junho de 1993, se comprovar o envolvimento de representantes da empresa ou da pessoa física contratada em práticas corruptas, fraudulentas, conluiadas ou coercitivas, no decorrer da licitação ou na execução do contrato financiado por organismo financeiro multilateral, sem prejuízo das demais medidas administrativas, criminais e cíveis;

15 São Paulo. Decreto 56.633, de 23 de Novembro de 2015. “Art. 1o O artigo 3o do Decreto no 44.279, de 24 de dezembro de 2003, passa

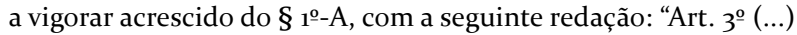

§ 1--A Os contratos administrativos deverão conter a seguinte cláusula anticorrupção: 'Para a execução deste contrato, nenhuma das partes poderá oferecer, dar ou se comprometer a dar a quem quer que seja, ou aceitar ou se comprometer a aceitar de quem quer que seja, tanto por conta própria quanto por intermédio de outrem, qualquer pagamento, doação, compensação, vantagens financeiras ou não financeiras ou benefícios de qualquer espécie que constituam prática ilegal ou de corrupção, seja de forma direta ou indireta quanto ao objeto deste contrato, ou de outra forma a ele não relacionada, devendo garantir, ainda, que seus prepostos e colaboradores ajam da mesma forma". 
Isso se verifica, por exemplo, na prática tornada comum de análise de contratos de parceiros comerciais com entidades governamentais, para verificação das respectivas margens, e para a investigação sobre eventual pagamento de propina a agentes públicos que possa estar diluído na remuneração da empresa. Esta forma de controle reverso da principiologia das licitações públicas - em que a análise do preço adequado é feita desde fora - não tem a força de anular, por si só, atos administrativos considerados ilícitos. Ela exerce, todavia, uma pressão significativa para que contratos públicos, em geral, sejam regulares, dando às empresas condições de atuarem relevantemente como denunciantes de ilicitudes detectadas. Mais até: ela ajuda a retirar oportunidades de negócios de empresas envolvidas em contratos suspeitos, desempenhando um papel que a ordem estatal tem dificuldades de se desincumbir, seja pela percepção viciada sobre o que constitui um contrato suspeito, seja porque o art. 19 da Lei Anticorrupção pressupõe um procedimento judicial um tanto burocrático.

No modelo de rede de compliance aqui proposto, opera-se uma espécie de dilema do prisioneiro inverso: aqui as partes não competem por ganho econômico direto, mas por uma expansão de práticas íntegras, sobretudo de natureza preventiva. O modelo regulatório será tão mais eficiente quanto maiores incentivos as empresas tiverem para se engajarem nessa rede; e o que se pode dizer é que, por conta da responsabilização objetiva prevista na Lei Anticorrupção, os primeiros resultados do incremento dessa forma de fazer negócios - a forma que vela para que os parceiros comerciais também façam a coisa certa - está ganhando corpo no país. ${ }^{16}$

Apenas um estudo empírico demonstraria se os custos das empresas, para atuarem em rede, são aumentados ou diminuídos. Pode-se especular que, no longo prazo, eles podem ser diminuídos pelo fenômeno da uberização do compliance - a adoção em larga escala de práticas de compartilhamento econômico, o que poderia ter um efeito direto na redução de custos, por padronização de técnicas e ferramentas de identificação e tratamento de situações de risco. A tendência seria no sentido de que essa forma de atuar implicaria, igualmente, a redução do próprio objeto a ser controlado, isto é, a diminuição de atos ilícitos, em geral. Ainda que significativa, a necessidade de investimento para iniciar e executar diversas tarefas, como, por exemplo, o registro independente de fornecedores, a contratação de auditorias externas etc, poderia ser compensada por essa dupla ordem de ganhos mencionada, o que revela o interesse da construção de um modelo teórico.

\section{DESAFIOS INTERPRETATIVOS NO BRASIL}

Enquadrado o tema no marco da governança global e no da rede de compliance que vai se formando no setor privado, é interessante cotejar a visão flexível que decorre desses vetores com os postulados mais tradicionais que caracterizam, ainda em grande medida, o direito público brasileiro. O enfrentamento teórico do assunto não poderia ser feito sem a advertência de que alguns avanços práticos já têm sido observados no país. É o caso, por exemplo, do ProÉtica, capitaneado pela Controladoria-Geral da União.

O Pró-Ética resulta da conjugação de esforços entre os setores público e privado para promover no país um ambiente corporativo mais íntegro, ético e transparente. A iniciativa consiste em fomentar a adoção voluntária de medidas de integridade pelas empresas, por meio do reconhecimento público daquelas que, independente do porte

16 No meio acadêmico, vale observar, o otimismo sobre o tema não é generalizado. Ainda em 2003, por exemplo, Cristine Parker apresentou críticas sobre como a análise de programas de compliance, feita por empresas terceirizadas de auditoria, retirava da arena pública boa parte da discussão sobre a aderência regulatória (PARKER, 2003, pp. 221-244). 
e do ramo de atuação, mostram-se verdadeiramente comprometidas com a prevenção e o combate à corrupção e outros tipos de fraudes.

A cada ano será realizado um evento para anúncio da lista anual e entrega da marca PróÉtica para as empresas. Também serão valorizadas e divulgadas as melhores práticas de integridade apresentadas no ano, para ampliar a publicidade em torno das empresas habilitadas. ${ }^{17}$

A descrição da iniciativa revela que, se não a análise comparativa dos programas para fins de multas, pelo menos o compêndio de programas, para fins de reconhecimento público e estatal, já está sendo feito no país, pelo governo central. Associada a tal fórmula, é de todo viável e desejável que a Administração elabore e divulgue documentos de diretrizes que guiem, em caráter de soft law, a tomada de decisões sobre programas de compliance no Brasil. É o que tem feito, por exemplo, o CADE,$^{18}$ em uma iniciativa que só pode se enriquecer se a entidade proceder, na maior medida possível, à análise comparativa de diversos programas. Isso pode ocorrer mediante a criação de um banco de dados, em termos práticos, e, sob uma visão mais normativa, de pareceres normativos que reflitam, ao menos indiretamente, os riscos identificados pelo próprio poder público, nas respectivas áreas de atuação; e que possam ser conhecidos pelas empresas que desejarem instaurar as melhores práticas em seus programas.

Os principais princípios constitucionais de baliza da atuação do poder público brasileiro, contudo, representam certo obstáculo nessa empreitada, para não falar de outras circunstâncias, igualmente difíceis de equacionar, que precisarão ser discutidas em outro trabalho, como é o caso da dispersão estrutural ocasionada pela divisão de competências na Federação. Como exercício reflexivo-argumentativo, seja dado passá-los em revista.

Princípio da Legalidade. Diversos comandos normativos já existem determinando o agir da Administração, deles se tirando uma noção geral de que à Administração é dado fazer somente o que está expressamente determinado em Lei. Mantida tal premissa, é inegável que o dever de avaliar o programa de integridade está na lei. Por sua vez, é também um comando normativo o de que a Administração deve sopesar diversos critérios, reconhecendo que a estrutura essencial do programa, nos termos do art. 41 do Decreto 8.420, de 18 de março de 2015, pressupõe um "conjunto de mecanismos e procedimentos internos", arquitetados não para satisfazer uma mera solenidade formal, mas para "detectar e sanar" acontecimentos reprováveis à luz da ordem jurídica.

Pois bem. Se o direito positivo brasileiro já contempla, no art. 41, parágrafo único, do Decreto, uma norma obrigando a que o programa de integridade se volte para "os riscos atuais da empresa", mas com olhos para o seu "constante aprimoramento e adaptação", parece lógico se concluir que, tanto na construção do que sejam os riscos inerentes à empresa, como na adoção das medidas cabíveis para a prevenção e o combate aos ilícitos associados a tais risco, é dever legal da Administração o conhecimento teórico e prático das questões relacionadas à empresa especificamente investigada, mas também daquelas que se igualam e desigualam a ela.

O legislador claramente quis determinar que as circunstâncias da empresa são relevantes para a determinação da adequação do seu programa. Entende-se que, nesse particular, ao dever explícito da empresa e da Administração de conhecerem os riscos e a adequação daquilo que foi feito para remediá-los, corresponde um dever implícito de alargar,

17 Brasil. Ministério da Transparência, Fiscalização e Controle. Disponível em: http://www.cgu.gov.br/assuntos/etica-e-integridade/ empresa-pro-etica. Acesso: o1 Jun. 2016.

18 Brasil. Conselho Administrativo de Defesa Econômica. Guia Programas de Compliance. Orientações sobre estruturação e benefícios da adoção de programas de compliance concorrencial. Disponível em: http://www.cade.gov.br/acesso-a-informacao/ publicacoes-institucionais/guias_do_Cade/guia-compliance-versao-oficial.pdf. Acesso em: 16 Jun. 2016. 
tanto quanto possível, o conhecimento sobre questões afetas que estejam em operação de outras empresas - sobretudo as boas práticas por elas adotadas na identificação dos riscos e na elaboração dos instrumentos de compliance. Não se desconhece que uma proposição é a de que o porte e as especificidades da empresa, listadas nos incisos do art. 42, do Decreto, são relevantes no procedimento de "avaliação dos parâmetros"; e que situação diversa é a de que a administração estaria autorizada, ou mesmo obrigada, a analisar os programas de integridade de outras empresas, de mesmo porte e especificidades, e cotejando-o com o programa de uma determinada empresa, considerar que esse deixou a desejar e foi, portanto, insatisfatório. Tal operação seria apenas natural, se prestigiada a finalidade pública maior de que o combate à corrupção deve ser intransigente, mas também perspicaz. Mas, a se levarem em condições outros princípios da Administração, algumas ressalvas podem ser colocadas.

Princípio da moralidade. ${ }^{19}$ Iniciativas de promoção da integridade podem facilmente ser alinhadas à observância do princípio da moralidade, se pensadas apenas desde um ponto de vista abstrato. Pormenorizando tais iniciativas é que se pode fazer um teste de interesse prático quanto ao atendimento dos comandos positivos e negativos que podem ser extraídos do princípio da moralidade; e, sem dúvida, esse teste coloca algumas dificuldades, quando se pensa na proposta de tornar mais corriqueira a análise comparativa dos programas de compliance. Então, compreende-se como fundamental que o setor público encarte a "ética da sustentabilidade" a compor um controle em rede, imiscuindo moral e direito, bem como agentes públicos e privados. Deixa-se de lado o culto à personalidade, ao pessoal, muitas vezes visto na publicidade estatal. Esse tipo de ética de combate à corrupção deve ser feito de forma sistêmica, até porque há uma correlação entre a boa governança e baixa corrupção, ${ }^{20}$ e um interesse simultaneamente público e privado em seu alcance.

Princípio da impessoalidade. Vista sob o angulo da impessoalidade, qualquer aplicação da lei deveria ser feita sem considerar o indivíduo ou a empresa destinatária, mas, sim, o status jurídico ostentado por eles, em tese replicável para qualquer outro que se encontre em situação semelhante. Semelhante garantia serve de proteção à boa-fé, não só sob a ótica daqueles que transgrediram preceitos obrigatórios e encontraram o beneplácito da Administração por vínculos pessoais, mas sob a ótica daqueles que, de fato, cumpriram os comandos pertinentes; e que se veem perseguidos pelos ocupantes de posições dentro da Administração por motivos espúrios, ligados à pessoa, e não ao seu status jurídico. Daí a importância de a Administração objetivar, na medida do possível, as lições aprendidas pela metodologia do benchmarking, construindo as bases para que a análise dos programas de compliance, ao tempo em que leve em consideração as peculiaridades de cada empresa, possa ir, aos poucos, incorporando as boas práticas que apenas algumas delas venham a adotar espontaneamente.

Um exemplo embrionário é o do funcionamento do Pró-Ética. ${ }^{21}$ Dotado de um Comitê Gestor formado por representantes da CGU, do Instituto Ethos e de entidades e instituições 19 Coube a Maurice Hauriou (1921) o tratamento pioneiro da matéria. Ao analisar o caso Gommel, julgado pelo Conselho de Estado francês, acaba concluindo que a moralidade é um instituto apartado da legalidade. Apesar disso, o autor francês, nas primeiras edições de seu livro, não trouxe um conceito de moralidade administrativa, porque apenas abordou o tema sem preencher o conteúdo do instituto em pauta. Em resumo, entendia que, tanto o recurso por détournement de pouvoir, como aquele que visava a corrigir a violation de la loi tinham por meta a manutenção de uma ação administrativa regular. Mas, para o autor, ambas as impugnações tinham bases dogmáticas diversas. Não se tarda para perceber que o pensamento de Maurice Hauriou era, na verdade, circular. Marcel Waline (1963, p. 489), ainda no começo do século XX, criticou com muita propriedade a tese exposta pelo primeiro autor, afirmando que a disciplina da ética pública advém de uma disciplina inserida no interior da Administração Pública. Ela advém de violações às premissas regulamentares, o que, de certo, viola a própria legalidade. Aliás, para este doutrinador, o desvio de poder busca fundamento no espírito da lei. Violar este padrão seria violar a própria lei. Então, afirma que o conceito de Hauriou não conseguiu distanciar-se de uma "ética da legalidade" que, no final, era a própria legalidade em si. Notou, enfim, que o desvio de poder é uma variação da ilegalidade. Então, entende-se que a tese exposta por Hauriou aproxima amiúde os conceitos de finalidade e de moralidade, tornando-os quase que sinônimos, uma vez que esta é quase que um resumo das finalidades perseguidas pelo Poder Público. A moralidade, então, não passaria do espectro teleológico que compõe os entes públicos.

20 Por exemplo: o direito sueco não faz mais diferença entre a corrupção pública e privada desde 1970.

21 O regulamento do Pró-Ética encontra-se disponível em: http://www.cgu.gov.br/assuntos/etica-e-integridade/empresa-pro-etica/ arquivos/documentos-e-manuais/novo-regulamento-empresa-pro-etica. Acesso: 27 Jun. 2016. 
convidadas dos setores público e privado, o Pró-Ética traz alguns requisitos documentais objetivos de admissibilidade; ${ }^{22}$ e visa a identificar aspectos específicos do funcionamento do programa, abarcando o comprometimento da alta direção e compromisso com a ética; as políticas e procedimentos internos; a comunicação e os treinamentos; os canais de denúncias e remediação; a análise de risco e monitoramento; a transparência e responsabilidade no financiamento político e social. ${ }^{23}$ Em caráter voluntário e desvinculado de qualquer procedimento sancionador, a Administração examina alguns aspectos do programa. A situação fática, em verdade, é a de que vários programas são avaliados e, inevitavelmente, aspectos positivos e negativos detectados podem ser cotejados pela Administração. Com base em tais elementos tornam-se públicas, anualmente, "as melhores práticas de integridade (...) com o objetivo de reconhecer, destacar e divulgar as empresas responsáveis por aquelas práticas e incentivar a adoção dessas boas práticas por outras empresas". ${ }^{24}$

É interessante destacar, retomando a ideia de como tal iniciativa representa, em certa medida, a superação do princípio da impessoalidade, que o critério utilizado para identificar tais práticas abarca a inovação e a consistência da medida de integridade. ${ }^{25}$ De fato, apenas com essa perspectiva comparativa se poderia mesmo conceber quais medidas possuem caráter inovador; e somente com esse sopesamento, a consistência da medida poderia ser examinada, em sua potencial aplicabilidade para outras empresas.

Princípio da publicidade. São várias as condicionantes impostas por esse princípio a qualquer agir da Administração. Ao contrário de um procedimento administrativo de responsabilização, em que apenas o programa da empresa investigada será analisado - e em que o princípio irá impor à Administração unicamente o dever de tornar público alguns elementos do procedimento -, uma versão alargada do escopo de análise dos programas deve ser cuidadosamente examinada, no que afetado pela publicidade. Seriam diversas as razões para se dar amplo conhecimento a quaisquer atos administrativos praticados em matéria de compliance, mas o fato é que, muitas vezes, questões ligadas ao sigilo das informações das empresas reclamariam certas limitações. O princípio da publicidade, ao pressupor uma quase automática divulgação de informações por parte do poder público, operaria como um desincentivo a que algumas empresas compartilhassem suas boas práticas; e, ao mesmo tempo, agiria como um dos maiores catalizadores dos efeitos positivos do benchmarking aqui proposto, a saber, a circulação mesma das boas práticas. O já exposto modelo da rede de integridade, em alguma medida, poderia atenuar os aspectos negativos desses efeitos, mas o certo é que o princípio da publicidade, por si só, é problemático o suficiente para merecer estudos em separado.

Admitida a possibilidade de utilização da metodologia aqui proposta, naturalmente põe-se a pergunta sobre quais critérios vão ser usados para se definirem os casos em que o exame múltiplo será feito. Como definir as empresas? Uma vez que o programa tenha sido analisado, também seria afeta à publicidade a eventual divulgação do risco que afeta a(s)

22 Art. 8o A Secretaria-Executiva do Comitê Gestor apenas analisará as informações e os documentos encaminhados pelas empresas que cumprirem os seguintes requisitos no ato da inscrição: I - não constar do Cadastro de Empresas Inidôneas e Suspensas - CEIS, do Cadastro Nacional de Empresas Punidas - CNEP ou do Cadastro de Entidades Privadas Sem Fins Lucrativos Impedidas - CEPIM; II - preencher o campo de resposta de todas as perguntas do questionário de avaliação e apresentar documentos comprobatórios; III - possuir Código de Ética ou documento equivalente; IV - submeter o questionário de avaliação no prazo estipulado; V - apresentar as certidões que comprovem a regularidade fiscal no âmbito federal e trabalhista, quais sejam: a) Certidão de Regularidade Fiscal emitida pela Secretaria da Receita Federal do Brasil (RFB) e pela Procuradoria-Geral da Fazenda Nacional (PGFN); b) Certificado de Regularidade do FGTS- CRF; e c) Certidão de Débitos Trabalhistas, para comprovar a inexistência de débitos inadimplidos perante a Justiça do Trabalho. VI - comprovar ser signatária do Pacto Empresarial pela Integridade e contra a Corrupção, promovido pelo Instituto Ethos de Empresas e Responsabilidade Social, a Patri Relações Governamentais \& Políticas Públicas, o Programa das Nações Unidas para o Desenvolvimento (Pnud), o Escritório das Nações Unidas contra Drogas e Crime (UNODC) e o Comitê Brasileiro do Pacto Global.

23 Art. 9ํ do Regulamento.

24 Art. 16 do Regulamento.

25 Art. 16, parágrafo 2o, do Regulamento. 
empresa(s) paradigma(s); e, com muito mais razão, a divulgação das opções comerciais que as tal(is) empresa(s) tenha(m) feito para lidar com ditos riscos?

Pode-se novamente olhar para o Pró-Ética como uma iniciativa relevante no assunto. Se o lado negativo da corrupção pode ter uma publicidade forçada, com a inserção de empresas em cadastros públicos de idoneidade, o lado positivo permanece dotado de um caráter voluntário: apenas as empresas que quiseram participar do Pró-Ética teriam os seus dados analisados para a elaboração da "lista de honra". A contrapartida disso, mais do que levar ao conhecimento do poder público os dados formais do programa, envolveria também descrever - se bem que, com alguma dose de discrição - a substância do programa, isto é, o conjunto de boas práticas. Dar-se-ia, aqui, um movimento pendular de observância e de distanciamento da publicidade, conforme a empresa expressamente autorizasse, ou não, o detalhamento e divulgação de suas ações específicas em matéria de compliance. Contudo, formado um arcabouço de informações, com os dados e fatos levados a conhecimento do poder público por empresas identificadas e identificáveis, a Administração poderia extrair os mais relevantes aspectos conceituais e passar a lhes dar uma destinação pública, ainda que os respectivos nomes das empresas fossem omitidos. Uma forma de viabilizar semelhante estrutura, por exemplo, seria a manutenção de acesso restrito a determinados bancos de dados internos, acompanhada, porém, da elaboração e divulgação de diretrizes e comentários a casos concretos sem referência nominal às respectivas empresas.

Princípio da eficiência. Do ponto de vista da eficiência, talvez não se poderia imaginar que seja exatamente eficiente a análise prévia de mais de um programa de integridade, para o fim de mais adequadamente avaliar um único programa que esteja em questão. Não haveria, aí, eficiência, em todo caso, se se considerar que o mesmo resultado (avaliação do programa da empresa $\mathrm{X}$ ) poderia ser alcançando com menor esforço (uma vez que não haveria também a avaliação dos programas das empresas $\mathrm{Y}$ e Z, atuantes no mesmo setor que X). Essa linha de raciocínio não responde, porém, à proposta mais ampla que aqui tem sido defendida, e que se reflete, por exemplo, na estrutura montada para o funcionamento do Pró-Ética. No mais, mesmo que se reduzisse o benchmarking a casos individuais, sem jamais cogitar de um corpo administrativo todo ele voltado para uma análise em bloco dos programas de compliance, a questão, do ponto de vista da eficiência, seria saber se uma avaliação feita nessas condições (com menor esforço) teria a mesma qualidade; e se, progressivamente, a análise de diversos programas não poderia ir se incorporando ao acervo de conhecimento adquirido da Administração, de forma organizada, a ponto de configurar um verdadeiro sistema de análise comparado.

Existem elementos empíricos nessa investigação que não podem ser investigados abstratamente. Os recursos materiais e humanos à disposição da Administração para implementar tal análise, seja ela comparativa ou individual, evidentemente influenciam a qualidade do serviço e podem justificar a escolha de formas de trabalho que se valham, ou não, do benchmarking. Em se tratando de um fenômeno recente no ordenamento brasileiro, a visão comparatista poderia render frutos, no longo prazo, mesmo que a estrutura administrativa ainda não permita a sua imediata e larga utilização. Se se construir a memória técnica sobre o tema de maneira arraigada à metodologia do benchmarking, o futuro que se desenhará a partir de então contará com um conjunto mais qualificado de informações, o que se coaduna com diversos outros postulados modernos do direito administrativo, como a análise de impacto regulatório.

No entanto, parece haver claras margens no ordenamento jurídico para se aumentar a exposição da Administração aos programas de compliance das empresas, mesmo que fora do ambiente de um procedimento administrativo de responsabilização, voltado para a 
apuração de uma ilicitude concreta, ou de uma iniciativa como o Pró-Ética. Com maior ou menor necessidade de edição de novos instrumentos legais, pode-se pensar na inserção da existência de um programa de compliance de qualidade como critério de pontuação em licitações públicas; como requisito para a obtenção de benefícios fiscais, regimes tributários especiais ou financiamentos públicos; como parte da demonstração de habilitação técnica em licenciamentos ambientais etc. A lista seria extensa e, em verdade, poderia colocar em um novo patamar boa parte das relações jurídicas travadas com a Administração, sem que necessariamente se criassem novos encargos para empresas e exigindo da Administração, mais do que qualquer outra coisa, somente uma mudança de cultura.

\section{CONCLUSÕES}

O combate à corrupção deve ser implementado a partir de um ofício criativo. Assim o impõe a natureza mesma das práticas que se quer evitar com a montagem de programas de integridade: feitas às escuras, encobertas, com propósitos distintos daqueles que são divulgados, e valendo-se da probabilidade de que aqueles que eventualmente descobrirem o malfeito terão uma visão apenas parcial do esquema. Vale lembrar, aqui, o insight do Padre Brown, famoso personagem das histórias de detetive do escritor inglês, Gilbert Keith Chesterton, e transcrito na epígrafe deste escrito. Naquela passagem, o Padre Brown elucida como foi possível deduzir os passos de um criminoso ao literalmente ouvir... os passos do criminoso. (CHESTERTON, 2005, p. 86). Os programas de integridade têm esse quê de busca por pistas indiretas e por vezes inusitadamente diretas. Isso decerto influencia a própria lógica com a qual a Administração irá avaliar tais programas - uma tarefa fadada ao insucesso se feita com amarras a formalidades burocráticas e acometida por um estrabismo que superdimensiona o que está nos autos apenas para ignorar o que está ao seu redor. De modo que o presente estudo procurou testar essas premissas especificamente quanto à análise de programas de integridade, segundo os parâmetros do art. 42 do Decreto 8.020/15, com a incorporação de um exame sobre as melhores práticas adotadas por outras empresas.

O marco teórico da governança global, que, no fundo, traduz-se como um esforço contra as variadas formas de corrupção e imposturas regulatórias, dá fundamento à proposta aqui defendida. A governança global pode ser entendida como um conjunto de práticas e orientações jurídicas diretamente afetando empresas e governos de todo o mundo na busca pela construção de uma ordem normativa adequada: uma ordem criativa, fluida, colaborativa e persuasiva. Os programas de compliance, pela posição independente que devem desempenhar no funcionamento das empresas, podem ser modelados a tal finalidade; eles cumprem o papel de instrumentalizar a governança, potencializando os efeitos da regulação estatal e de outras fontes jurídicas que cada vez mais ganham espaço como mecanismos para promover o jeito certo de se fazer negócios.

A observação sobre o alcance de tais programas permite entrever a formação de uma rede de compliance: uma série de práticas e iniciativas adotadas pelas empresas como subprodutos da regulação em geral, mas que se materializam em caráter mais ou menos espontâneo, de interferência negocial preventiva em relação a outras empresas percebidas como apresentando riscos de corrupção ou de descumprimento de comandos regulatórios. Essa engenhosa rede de compliance é uma das bases de sustentação para uma postura dir-se-ia mais vanguardista também por parte da Administração Pública: uma postura de encarar a regulação como um mecanismo dinâmico e constantemente responsivo a opções das empresas, e, portanto, uma postura de encarar os programas de compliance como algo que pode ser aprimorado com base 
em experiências positivas e negativas que as próprias empresas tenham vivenciado no dia-adia de seus negócios.

No Brasil, tal vanguardismo pode superar as limitações que, em uma primeira análise, poderia se imaginar como sendo impostas à Administração Pública pelos tradicionais princípios da legalidade, da moralidade, da impessoalidade, da publicidade e da eficiência. Para se chegar ao resultado aqui defendido, esses princípios, na verdade, precisam ser apenas bem compreendidos. Quando busca conhecer, nos programas de compliance de mais de uma empresa, quais são as melhores técnicas e práticas na identificação e tratamento dos riscos de corrupção ou de descumprimento regulatório, a Administração Pública, naturalmente, está prestigiando os princípios constitucionais desde um nível amplo - desde o nível pelo qual as regras jurídicas devem ser cumpridas, da melhor maneira possível, por todos indivíduos e empresas; e devem se fazer cumprir, da melhor maneira possível, pelas autoridades reguladoras, especialmente aquelas encarregadas de fiscalizar os mecanismos de compliance.

Isso não significa que a metodologia do benchmarking para a análise comparativa de programas de compliance esteja imune a problemas. Quase um mandamento de gestão no setor privado, o benchmarking se conciliaria mesmo com os princípios constitucionais de balizamento da Administração? A dedução é tormentosa. Aplicar a lei de maneira igual a todos significa, mesmo quando se estabelecem critérios distintivos para indivíduos em situações desiguais, encontrar na própria lei os postulados que devem ser seguidos por aqueles que se encontrarem em situações fáticas ou jurídicas semelhantes. Daí que não seria válido percorrer o caminho inverso, para, antes de aplicar o postulado normativo, determinando o seu significado, examinar a situação geral dos destinatários, verificar em qual medida eles estão adaptados ao comando normativo e, mais até, escolher qual deles melhor atendeu ao preceito para então impor aos demais uma conduta igualmente exemplar, exigindo mais de que já simplesmente houvera cumprido os parâmetros da lei, ou exigindo menos, simplesmente porque a coletividade relevante não está conseguindo mesmo alcançar o parâmetro desejado pelo legislador. Essa flexibilidade seria estranha ao direito público, mas, em muitas ocasiões, é exatamente a partir dessa conduta de espontânea colaboração que muitos programas de integridade surgiram e estão surgindo nas empresas brasileiras. Para uma Administração que por anos ignorou por completo essa questão, existem bases teóricas, pois, para se aproveitar das lições positivas e negativas assim aprendidas, desenhando, no futuro, um regime regulatório que expressamente contemple a distinção da qualidade dos programas de compliance como um dado objetivo a ser levado em consideração em diversos tópicos do direito administrativo, como, por exemplo, os contratos administrativos.

Assim, para que se estabeleça uma "governança multilateral" em termos de programas de integridade, faz-se necessário um aprofundamento dos mecanismos legais, institucionais e culturais existentes, consistentes nas ações na área das questões corporativas. A ampliação da interface da compliance, neste aspecto, além de uma "pequena política", representada pelos assuntos econômicos e sociais, inclui uma "alta política", representada pelas questões de segurança, diplomacia preventiva e negociações etc.

De outro lado, em termos de Estado, considera-se fundamental que se compreenda o modelo atual de gestão pública, aludindo a problemas reais e preocupantes, a partir de metas de qualificação da gestão. Pensar o Estado diante da complexidade social sugere a necessidade de desenvolvimento de ferramentas sustentáveis e de uma nova forma de gestão dos interesses públicos, especialmente quando relacionados aos negócios jurídicos das empresas que movimentam a economia. 


\section{REFERÊNCIAS}

AMBROSE, Jim; BURKE, Laurel; HORWATH; PENN, Doug; WOODS, Monica. Compliance Program Standardization: Myth or Reality? Preventive Law Reporter, Vol. 14, 1995, pp. 8-45.

ARAGÃO, Alexandre Santos. Agências reguladoras e a evolução do direito administrativo econômico. 3. ed. rev. e atual. Rio de Janeiro: Forense, 2013.

BATISTA, Antenor. Corrupção: Fator de Progresso? 5aㅡ ed. São Paulo: Letras \& Letras, 1991.

BATISTA JÚNIOR, Onofre Alves. Princípio constitucional da eficiência administrativa. Belo Horizonte: Mandamentos, 2004.

BRONSON, Mark; JOHNSON, Michelle; SULLIVAN, Kate. International Transfer Pricing. Law, Tax Planning and Compliance Strategies. Chapter 1: Overview/Best Practices. In: Transfer Pricing Insights. A Collection of Technical Articles by Ceteris Professionals. Vol. 2. 2011.

CCI - Câmara de Comércio Internacional. Cláusula Anticorrupção da CCI. 2012. Disponível em: http://www.cgov.pt/images/stories/ficheiros/clausula_anticorrupcao_da_icc. pdf. Acesso em: p. 30 Mai. 2016. p. 6.

CANE, Peter. Administrative law. Londres: Oxford University Press, 2011.

CARVALHO, Olavo de. O poder de conhecer. In: O mínimo que você precisa saber para não ser um idiota. 15 $5^{\mathrm{a}}$ ed. Record: Rio de Janeiro, 2015.

CHESTERTON, Gilbert Keith. The Queer Feet. In: G.K Chesterton Collected Works. Vol. XII. Father Brown Stories. Part I. San Francisco: Ignatius, 2005

DOWNS, George W.; JONES, Michael A. Reputation, Compliance, and International Law. The Journal of Legal Studies, Vol. 31, 2002, pp. 95-114.

FAORO, Raymundo. Donos do Poder. 10 ed. São Paulo: Globo, 2000.

FERNANDES DIAS, Bruno. Submissão de Documentos e Informações a Autoridades Estrangeiras: o Regime Jurídico do Art. 188 da CRFB/88 e as Leis de Bloqueio. Cadernos do Programa de Pós-Graduação em Direito da UFRGS. v. 10, n.1, 2015, pp. 322-367. Disponível em: http://seer.ufrgs.br/index.php/ppgdir/article/view/53853/34754. Acesso: 12 Jun. 2016.

FREMOND, Olivier; CAPAUL, Mierta. The State of Corporate Governance: Experience from Contry Assessments. World Bank Policy Research Working Paper 2858. June 2002. Disponível em: http://papers.ssrn.com/sol3/papers.cfm?abstract_id=636222. Acesso em: 12 Jun. 2016.

FURTADO, Lucas Rocha. As Raízes da Corrupção no Brasil. Estudos de Casos e Lições para o Futuro. Belo Horizonte: Editora Forum, 2015. 
GRIFFITH, Sean J. Corporate Governance in an Era of Compliance. William\& Mary Law Review, Vol. 57, No. 6, 2016. Fordham Law Legal Studies Research Paper No. 2766661. Disponível em: http://papers.ssrn.com/sol3/papers.cfm?abstract_id=2766661. Acesso: 13 Jun. 2016. pp. 2118-2119.

HAURIOU, Maurice. Précis de droit administratif et de droit public. Paris: Sirey, 1921.

HEINEN, Juliano. Comentários à Lei Anticorrupção. Belo Horizonte: Fórum, 2015.

CLÁUSULA Anticorrupção da ICC. International Chamber of Commerce. Disponível em: http:// www.cgov.pt/images/stories/ficheiros/clausula_anticorrupcao_da_icc.pdf. Acesso em: p. 30 Mai. 2016. p. 6.

OCDE - Organização para a Cooperação e Desenvolvimento Econômico. Compliance Risk Management: Managing and Improving Tax Compliance, pp. 37-45. Disponível em: http:// www.oecd.org/dataoecd/21/55/37212610.pdf. Acesso em: o1 Jul. 2016.

PARKER, Christine. Regulator-Required Corporate Compliance Program Audits. Law \& Policy. Vol. 25, 2003, pp. 221-244.

RIVERO, Jean. Direito administrativo. Coimbra: Almedina, 1981 Droit administratif. Paris: Dalloz, 1983.

VALENTE DOS REIS, Gabriel. Aplicação do Direito Estrangeiro sob a Ótica Cosmopolita. Tese de Doutorado apresentada, em 2016, ao Programa de Pós-Graduação da Faculdade de Direito da Universidade de São Paulo (Largo São Francisco).

WALINE, Marcel. Droit administratif. Paris: Sirey, 1963, 